\title{
FAKTOR-FAKTOR YANG MEMPENGARUHI IBU DALAM PEMBERIAN ASI EKSKLUSIF DI DESA PUCANGANOM KECAMATAN GIRIWOYO KABUPATEN WONOGIRI
}

\author{
Oleh : \\ Sri Aminingsih ${ }^{1}$, Lucia Desi Puti ${ }^{2}$
}

\begin{abstract}
Background Breastfeeding will ensure babies stay healthy and start life in the most healthy. Breastfeeding is actually not only allows the baby to grow up to be healthy physically, but also more intelligent, stable had a emotional, spiritual development, and positivesocial development. Riskesdas 2010 coverage of exclusive breastfeeding in Indonesia is still far from the world average and still very far from the target of Healthy Indonesia 2010. In rural districts Pucanganom Giriwoyo of the initial interview 3 of 5 mothers to breastfeed exclusively, while 2 others are not breastfed exclusively with reasons having to work, lack of time and because of no discharge of breast milk.

The purpose to find out the factors that affect the mother in exclusive breast feeding in the village of Pucanganom sub-district of Giriwoyo Regency Wonogiri.

Method of this research is descriptive research. While the plan is cross sectional used to find out the factors that affect the mother in exclusive breast feeding. Then there searchers took data from respondents regarding the factors that affect breast feeding.

The Result Factors that affect the exclusive breast feeding is the age of the mother, the mother's education, number of children, mother's work and family income. The most exclusive breast feeding on mother's age 26-45 years $(83,33 \%)$, maternal education high school-undergraduate $(70 \%)$, given on the first and second child(73,34\%), employment of the mother as a homemaker (73,34\%), and family income $1-3$ million (76.67\%).

Conclusion the mother who does not work it's possible giving exclusive breast milk due to the considerable amount of time which can be used by the mother to nurture her baby even 24 hours time the mother could be given to her baby, therefore breast feeding can be done during the first 6 months of the birth ofthe baby.
\end{abstract}

Keywords: Exclusive breast feeding

\section{PENDAHULUAN}

Menurut Departemen Kesehatan Republik Indonesia (2008), sebagaimana dikutip oleh Haryono dan Setianingsih (2014), Angka Kematian Bayi (AKB) merupakan salah satu indikator penting dalam menentukan tingkat kesehatan masyarakat, baik pada tatanan provinsi maupun nasional. Hasil Survei Demografi Kesehatan Indonesia (SDKI) tahun 2007 melaporkan AKB di Indonesia adalah 34 per 1000 kelahiran hidup. Kendati terus mengalami penurunan, AKB di Indonesia masih jauh lebih tinggi jika dibandingkan dengan negara-negara anggota ASEAN lainnya, AKB di Singapura yaitu 3 per 1000 kelahiran hidup, Brunai Darussalam 8 per 1000, Malaysia 10 per 1000, Vietnam 18 per 1000 dan Thailand 20 per 1000.

Menurut Hasil Riset Kesehatan Dasar (2007), sebagaimana dikutip oleh Haryono dan Setianingsih 
(2014), proporsi penyebab kematian bayi usia 0-11 bulan yang tertinggi ialah karena diare yaitu sebesar $42 \%$, diikuti pneumonia $24 \%$, meningitis/ensefalitis $9 \%$, kelainan saluran pencernaan sebesar $7 \%$, kelainan jantung kongenital dan hidrosefalus $6 \%$, sepsis $4 \%$, tetanus $3 \%$, dan penyebab lain-lain (malnutrisi, TB, campak) sebesar $5 \%$. Menurut hasil penelitian Story dan Parish (2011), sebagaimana dikutip oleh Haryono dan Setianingsih (2014), kematian bayi bisa diturunkan dengan pemberian ASI Eksklusif, secara signifikan ASI menurunkan insiden diare dan infeksi saluran pernafasan.

Menyusui akan menjamin bayi tetap sehat dan memulai kehidupannya dengan cara yang paling sehat. Menyusui sebenarnya tidak saja memberikan kesempatan pada bayi untuk tumbuh menjadi yang sehat secara fisik, tetapi juga lebih cerdas, mempunyai emosional yang stabil, perkembangan spiritual yang positif, serta perkembangan sosial yang lebih baik. (Haryono dan Setianingsih, 2014)

Air Susu Ibu (ASI) merupakan nutrisi alamiah terbaik bagi bayi karena mengandung kebutuhan energi dan zat yang dibutuhkan selama enam bulan pertama kehidupan bayi. Namun, ada kalanya seorang ibu mengalami masalah dalam pemberian ASI. Kendala utama adalah karena produksi ASI tidak lancar. (Saleha, 2009)

Menurut Allen dan Amiruddin (2006), sebagaimana dikutip oleh Haryono dan Setianingsih (2014), bahwa ASI sebagai penyelamat kehidupan. Di Indonesia setiap tahunnya lebih dari 25.000 bayi dan 1,3 juta bayi diseluruh dunia dapat diselamatkan dengan pemberian ASI Eksklusif.

ASI merupakan makanan utama bagi bayi sehingga sangat penting untuk kesehatan bayi, namun tidak semua bayi mendapatkan ASI dari ibunya. Menurut UNICEF, cakupan rata-rata ASI Eksklusif didunia yaitu $38 \%$. Menurut SDKI dari tahun 1997 hingga 2002, jumlah bayi usia 6 bulan yang mendapatkan ASI Eksklusif menurun dari $7,9 \%$ menjadi $7,8 \%$. Sementara itu, hasil SDKI 2007 menunjukkan penurunan jumlah bayi yang mendapatkan ASI Eksklusif hingga 7,2\%. Riskesdes 2010 juga melaporkan jumlah bayi yang menyusu ASI Eksklusif sampai usia 6 bulan di Indonesia hanyalah sebanyak $15,3 \%$, sedangkan target Indonesia Sehat 2010 cakupan ASI Eksklusif adalah sebanyak $80 \%$. Dari data diatas dapat disimpulkan bahwa cakupan ASI Eksklusif di Indonesia masih jauh dari rata-rata dunia dan juga masih sangat jauh dari Target Indonesia Sehat 2010. (Haryono dan Setianingsih, 2014)

Dari survey awal yang dilakukan peneliti pada Desa Pucanganom Kecamatan Giriwoyo Kabupaten Wonogiri, diambil 5 orang untuk dilakukan wawancara. Diperoleh data 3 dari 5 ibu lebih memilih memberi ASI eksklusif, ibu tersebut mengatakan bahwa dengan pemberian ASI eksklusif akan mengurangi pengeluaran sehari-hari selain itu anak jarang sakit karena pada bayi usia 0-6 bulan sangat membutuhkan ASI untuk pertumbuhan, perkembangan otak bayi, dan pertambahan kekebalan tubuh bayi, kemudian 2 diantara ibu tersebut lebih memilih tidak memberikan ASI eksklusif karena harus berkerja, kurangnya waktu dalam menyusui, dan karena faktor tidak keluarnya ASI eksklusif sehingga ibu tersebut lebih memilih memberikan susu formula pada bayinya.

\section{TUJUAN PENELITIAN}

Untuk mengetahui faktor-faktor yang mempengaruhi ibu dalam pemberian ASI eksklusif di Desa Pucanganom Kecamatan Giriwoyo Kabupaten Wonogiri. 


\section{METODE PENELITIAN}

Desain penelitian merupakan bentuk rancangan yang digunakan dalam melakukan prosedur penelitian.

Penelitian ini merupakan penelitian deskriptif. Sedangkan rencana yang digunakan adalah cross sectional untuk mengetahui faktor-faktor yang mempengaruhi ibu dalam pemberian ASI eksklusif. Maka peneliti mengambil data dari responden mengenai faktor yang mempengaruhi pemberian ASI eksklusif.

Populasi yang akan digunakan dalam penelitian ini adalah ibu yang mempunyai anak berusia minimal 7 bulan di Desa Pucanganom Kecamatan Giriwoyo Kabupaten Wonogiri adalah sejumlah 35 orang, 5 orang untuk observasi awal, jadi jumlah responden yang digunakan adalah 30 orang.

\section{HASIL PENELITIAN}

1. Karakteristik Responden

Berdasarkan penelitian yang telah dilakukan mulai bulan Maret 2015 didapatkan karakteristik

responden sebagai berikut :

Tabel 1. Distribusi Frekuensi Karakteristik Responden Berdasarkan Usia

\begin{tabular}{ccc}
\hline $\begin{array}{c}\text { Kelompok } \\
\text { Umur lbu (Th) }\end{array}$ & $\mathbf{f}$ & $\%$ \\
\hline $20-25$ & 5 & 16,67 \\
\hline $26-45$ & 25 & 83,33 \\
\hline Total & 30 & 100 \\
\hline
\end{tabular}

Dari tabel di atas diperoleh informasi bahwa responden dengan kelompok umur 20-25 tahun berjumlah 5 responden $(16,67 \%)$, kelompok umur $26-45$ tahun berjumlah 25 responden $(83,33 \%)$.
Tabel 2. Tabel Distribusi Frekuensi Responden Berdasarkan Umur Anak

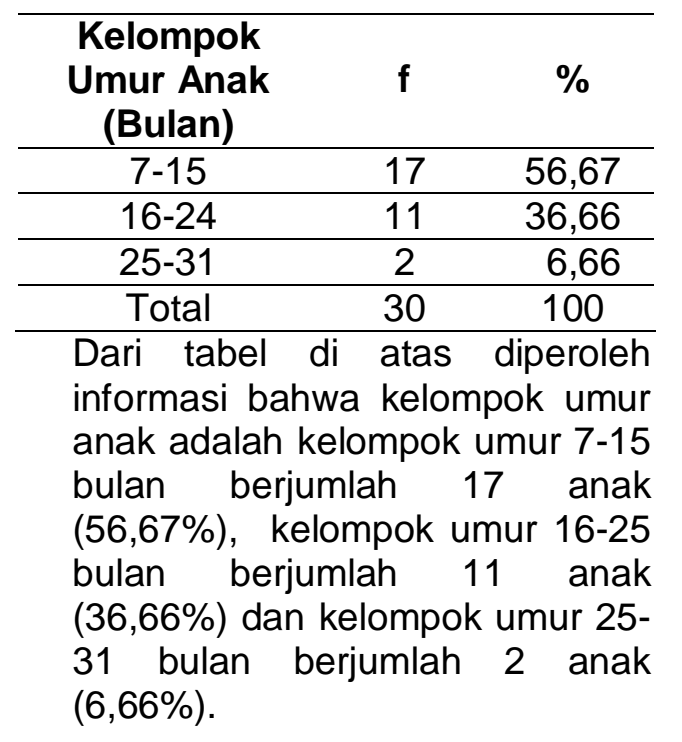

Tabel 3. Distribusi Frekuensi Karakteristik Responden Berdasarkan Kelahiran Anak

\begin{tabular}{ccc}
\hline $\begin{array}{c}\text { Kelahiran } \\
\text { anak }\end{array}$ & $\mathbf{f}$ & $\%$ \\
\hline $1-2$ & 22 & 73,34 \\
\hline $3-4$ & 7 & 23,33 \\
\hline $5-6$ & 1 & 3,33 \\
\hline Total & 30 & 100 \\
\hline
\end{tabular}

Dari tabel di atas diperoleh informasi bahwa berdasarkan kelahiran anak 1-2 berjumlah 22 $(73,34 \%)$, kelahiran anak 3-4 berjumlah $7 \quad(23,33 \%)$ dan kelahiran anak 5-6 berjumlah $1(3,33 \%)$.

Tabel 4. Karakteristik Responden Berdasarkan Pekerjaan

\begin{tabular}{lcc}
\hline $\begin{array}{c}\text { Pekerjaan } \\
\text { lbu }\end{array}$ & $\mathbf{f}$ & $\%$ \\
\hline lbu rumah tangga & 22 & 73,34 \\
\hline Buruh pabrik & 4 & 13,33 \\
\hline Wiraswasta & 3 & 10 \\
\hline Buruh tani & 1 & 3,33 \\
\hline Total & 30 & 100 \\
\hline
\end{tabular}

Dari tabel di atas diperoleh informasi bahwa berdasarkan 
pekerjaan ibu sebagai ibu rumah tangga sebanyak 22 ibu (73,34\%), bekerja sebagai buruh pabrik sebanyak 4 ibu (13,33\%), bekerja sebagai wiraswasta sebanyak 3 ibu (10\%) dan bekerja sebagai buruh tani sebanyak 1 ibu (3,33\%).

Tabel 5. Karakteristik responden berdasarkan pendidikan

\begin{tabular}{lcc}
\hline Pendidikan & $\mathbf{f}$ & $\%$ \\
\hline SD-SMP & 7 & $30 \%$ \\
\hline SMA-S1 & 23 & $70 \%$ \\
\hline Total & 30 & 100 \\
\hline
\end{tabular}

Dari tabel di atas diperoleh informasi bahwa berdasarkan pendidikan responden dari SDSMP berjumlah 7 responden (30\%) dan SMA-S1 berjumlah 23 responden (70\%).

Tabel 6. Karakteristik responden berdasarkan penghasilan

\begin{tabular}{ccc}
\hline $\begin{array}{c}\text { Penghasilan } \\
\text { Keluarga }\end{array}$ & $\mathbf{f}$ & $\%$ \\
\hline$<1$ Juta & 6 & 20 \\
\hline 1- 3 Juta & 23 & 76,67 \\
\hline$>3$ juta & 1 & 3,33 \\
\hline Total & 30 & 100 \\
\hline
\end{tabular}

Dari tabel di atas diperoleh informasi bahwa berdasarkan penghasilan keluarga kurang dari 1 juta sebanyak 6 responden (20\%), penghasilan keluarga antara 1-3 juta sebanyak 23 responden $(76,66 \%)$, dan penghasilan keluarga lebih dari 3 juta terdapat 1 responden $(3,33 \%)$.
2. Hasil Penelitian

Tabel.7 Distribusi Frekuensi

Faktor Pemudah dalam

Pemberian ASI Eksklusif

\begin{tabular}{|c|c|c|c|c|}
\hline Variabel & \multicolumn{2}{|c|}{$\mathbf{Y a}$} & \multicolumn{2}{|c|}{ Tidak } \\
\hline & $f$ & $\%$ & $f$ & $\%$ \\
\hline \multicolumn{5}{|l|}{ Pengetahuan } \\
\hline $\begin{array}{l}\text { Pemberian } \\
\text { ASI }\end{array}$ & 28 & 93,33 & 2 & 6,67 \\
\hline Informasi ASI & 23 & 76,67 & 7 & 23,33 \\
\hline $\begin{array}{l}\text { ASI } \\
\text { menambah } \\
\text { BB }\end{array}$ & 28 & 93,33 & 2 & 6,67 \\
\hline \multicolumn{5}{|l|}{ Nilai Budaya } \\
\hline $\begin{array}{l}\text { ASI mencegah } \\
\text { bayi sakit }\end{array}$ & 30 & 100 & 0 & 0 \\
\hline $\begin{array}{l}\text { ASI wajib } \\
6 \text { bulan }\end{array}$ & 26 & 86,67 & 4 & 13,33 \\
\hline
\end{tabular}

Tabel 8. Distribusi Frekuensi

Faktor Pendukung dalam

Pemberian ASI Eksklusif

\begin{tabular}{lcccc}
\hline \multicolumn{2}{c}{ Variabel } & \multicolumn{2}{l}{ Ya } & \multicolumn{2}{l}{ Tidak } \\
\hline & f & $\%$ & f & $\%$ \\
\hline $\begin{array}{l}\text { Ketersediaan } \\
\text { waktu }\end{array}$ & & & & \\
\hline $\begin{array}{l}\text { ASI } \\
\text { mengurangi } \\
\text { pengeluaran }\end{array}$ & 26 & 86,67 & 4 & 13,33 \\
\hline $\begin{array}{l}\text { ASI } \\
\text { menambah } \\
\text { pendapatan }\end{array}$ & 15 & 50 & 15 & 50 \\
\hline $\begin{array}{l}\text { Pemberian } \\
\text { ASI tepat } \\
\text { waktu }\end{array}$ & 24 & 80 & 6 & 20 \\
\hline $\begin{array}{l}\text { Kesehatan Ibu } \\
\text { Ada riwayat } \\
\text { sakit }\end{array}$ & 1 & 3,33 & 29 & 96,67 \\
\hline
\end{tabular}


Tabel 9. Distribusi Frekuensi

Faktor Pendorong dalam

Pemberian ASI Eksklusif

\begin{tabular}{lcccc}
\hline \multirow{2}{*}{ Variabel } & \multicolumn{2}{c}{ Ya } & \multicolumn{2}{c}{ Tidak } \\
\cline { 2 - 5 } & $\mathbf{f}$ & $\%$ & $\mathbf{f}$ & $\%$ \\
\hline $\begin{array}{l}\text { Dukungan } \\
\text { keluarga }\end{array}$ & 29 & 96,67 & 1 & 3,33 \\
\hline $\begin{array}{l}\text { Dukungan } \\
\text { tenaga } \\
\text { kesehatan }\end{array}$ & 28 & 93,33 & 2 & 6,67 \\
\hline
\end{tabular}

\section{PEMBAHASAN}

Faktor-faktor yang mempengaruhi ibu dalam pemberian ASI menurut Haryono dan Setianingsih (2014), adalah sebagai berikut:

1. Faktor Pemudah (Predisposing Factor)

a. Pendidikan

Pendidikan akan membuat seseorang terdorong untuk ingin tau, untuk mencari pengalaman dan untuk mengorganisasikan

pengalaman sehingga informasi yang diterima akan menjadi pengetahuan. Pengetahuan yang dimiliki akan membentuk suatu keyakinan untuk melakukan perilaku tertentu.

b. Pengetahuan

Merupakan hasil stimulasi informasi yang diperhatikan dan diingat. Informasi tersebut bisa berasal dari pendidikan formal maupun non formal, percakapan, membaca, mendengarkan radio, menonton televisi dan pengalaman hidup.

c. Nilai-nilai dan adat budaya Adat budaya akan mempengaruhi ibu untuk memberikan ASI secara eksklusif karena sudah menjadi budaya dalam keluarga.

2. Faktor Pendukung (Enabling Factor)

a. Pendapatan keluarga
Pendapatan yang diperoleh dalam keluarga akan meningkatkan kualitas baik ASI, jika ibu mengkonsumsi makanan yang mengandung gizi.

b. Ketersediaan waktu

Waktu menyusui seorang ibu berkaitan erat dengan status pekerjaannya. Banyak ibu yang memberikan ASI karena banyak alasan, diantaranya karena harus kembali bekerja setelah cuti melahirkan selesai.

c. Kesehatan ibu

Kondisi kesehatan ibu mempunyai pengaruh yang sangat penting dalam kelangsungan proses menyusui.

3. Faktor Pendorong (Reinforcing Factors)

a. Dukungan keluarga

Dukungan dari keluarga termasuk orang tua atau saudara lainnya sangat menentukan keberhasilan menyusui, karena pengaruh keluarga berdampak pada kondisi emosi ibu sehingga secara tidak langsung mempengaruhi produksi ASI.

b. Dukungan petugas kesehatan

Petugas kesehatan yang profesional bisa menjadi faktor pendukung ibu dalam memberikan ASI. Dukungan tenaga kesehatan kaitannya dengan nasehat kepada ibu untuk memberikan ASI pada bayinya menentukan keberlanjutan ibu dalam pemberian ASI.

Seperti telah dijelaskan di atas secara teori bahwa faktor yang mempengaruhi ibu dalam pemberian ASI eksklusif terdapat 3 faktor. Bila dilihat dari faktor pemudah (predisposing factor) terdiri dari pendidikan, pengetahuan, nilai-nilai dan 
adat. Prosentase hasil penelitian berdasarkan 10 pertanyaan dari faktor pemudah dapat dijelaskan secara terperinci yaitu untuk pendidikan SD sampai SMP terdapat $30 \%$ sedangkan SMA sampai S1 terdapat $70 \%$. Kuesioner tentang pengetahuan diperoleh dari pertanyaan tentang pemberian ASI eksklusif didapatkan hasil 93,33\%, informasi ASI eksklusif 76,67\%, ASI menambah berat badan bayi $93,33 \%$. Kuesioner tentang nilai-nilai dan adat budaya diperoleh dari pertanyaan tentang ASI mencegah bayi jarang sakit $100 \%$, ASI wajib diberikan selama 6 bulan $86,67 \%$.

Faktor pendukung (enabling factor) yang mempengaruhi ibu dalam pemberian ASI eksklusif terdiri dari pendapatan keluarga, ketersediaan waktu dan kesehatan ibu. Prosentase pendapatan keluarga responden terdiri dari < 1 juta terdapat $20 \%$, 1 juta sampai 3 juta terdapat $76,67 \%$ sedangkan $>3$ juta terdapat $3,33 \%$. Prosentase ketersediaan waktu diperoleh dari pertanyaan tentang ASI mengurangi pengeluaran keluarga didapatkan hasil $86,67 \%$, ASI menambah pendapatan $50 \%$, pemberian ASI tepat waktu $80 \%$. Prosentase kesehatan ibu diperoleh dari pertanyaan tentang pemberian ASI mencegah ca mamae 96,67\%, pemberian $\mathrm{ASI}$ mencegah perdarahan $46,67 \%$.

Faktor pendorong (reinforcing factors) yang mempengaruhi ibu dalam pemberian ASI eksklusif terdiri dari dukungan keluarga dan dukungan petugas kesehatan. Prosentase dukungan keluarga diperoleh dari pertanyaan tentang stress melancarkan ASI 80\%, dukungan suami membuat semangat dalam pemberian ASI 96,67\%, sikap positif melancarkan ASI 83,33\%, ada motivasi membuat ASI lancar $86,67 \%$. Prosentase dukungan tenaga kesehatan diperoleh dari pertanyaan tentang dukungan tenaga kesehatan membuat percaya diri $93,33 \%$.

Berdasarkan hasil penelitian dari karakteristik responden dapat dijelaskan bahwa prosentase terbanyak untuk umur ibu yang memberikan ASI eksklusif adalah 26 - 45 tahun $(83,33 \%)$, prosentase terbanyak untuk umur anak yang telah diberi ASI eksklusif adalah 7 15 bulan ( $56,67 \%$ ), prosentase terbanyak untuk pendidikan ibu yang memberikan ASI eksklusif adalah SMA sampai S1(70\%), prosentase terbanyak untuk anak yang diberi ASI eksklusif adalah anak pertama dan kedua $(73,33 \%)$, prosentase terbanyak untuk pekerjaan ibu yang memberikan ASI eksklusif adalah ibu rumah tangga $(73,33 \%)$ dan prosentase terbanyak untuk pendapatan keluarga adalah 1-3 juta (76,67\%).

Dari uraian diatas dapat disimpulkan bahwa rata-rata ibu yang bisa memberikan ASI eksklusif adalah ibu rumah tangga dengan latar belakang pendidikan SMA sampai S1, dimana ibu sudah memiliki pengetahuan tentang ASI yang cukup terlihat dari paparan informasi yang diperoleh ibu dari tenaga kesehatan $60 \%$ dan dari buku $10 \%$.

Dari uraian tiga faktor yang mempengaruhi ibu dalam pemberian ASI eksklusif diatas bisa dijadikan gambaran bahwa ibu yang tidak bekerja sangat memungkinkan memberikan ASI 
eksklusif dikarenakan cukup banyak waktu yang bisa digunakan ibu untuk mengasuh bayinya bahkan 24 jam waktu ibu bisa diberikan untuk bayinya, oleh karena itu pemberian ASI bisa dilakukan selama 6 bulan pertama kelahiran bayi, selain itu pendidikan ibu rata-rata adalah SMA - S1 dimana tingkat pendidikan ibu ini bisa mendukung perolehan informasi yang diperlukan terutama tentang ASI eksklusif misalkan dari tenaga kesehatan, buku dan keluarga. Bila dicermati dari usia ibu saat memberikan ASI eksklusif adalah usia $26-45$ tahun dimana usia tersebut bisa dikatakan usia dewasa yang artinya ibu tidak hanya memutuskan sesuatu untuk kepentingannya sendiri yaitu memberikan ASI eksklusif melainkan justru lebih memikirkan yang terbaik untuk bayinya karena sudah terbukti bahwa pemberian ASI eksklusif pasti jauh lebih baik daripada susu formula.

Sebagai perbandingan dengan peneliti sebelumnya meskipun hasilnya berbeda dengan penelitian ini adalah penelitian yang dilakukan oleh Simanjuntak (2013), berjudul faktor-faktor dominan yang mempengaruhi ibu dalam pemberian ASI eksklusif di wilayah kerja Puskesmas Balige dapat disimpulkan responden yang memberikan ASI ekskusif sebesar $41 \%$, sedangkan responden yang tidak memberikan ASI eksklusif sebesar 59\%. Sedangkan penelitian yang dilakukan oleh Rahmawati (2012) dengan judul faktor-faktor yang mempengaruhi pemberian ASI eksklusif pada ibu menyusui di Kelurahan

Pedalangan
Kecamatan Banyumanik Kota Semarang dapat disimpulkan faktor paling dominan yang mempengaruhi pemberian ASI eksklusif adalah status pekerjaan yang menandakan bahwa ibu yang tidak bekerja berpeluang memberikan ASI eksklusif pada bayinya 4 kali dibanding ibu yang bekerja.

\section{KESIMPULAN}

1. Terdapat faktor - faktor yang mempengaruhi lbu dalam pemberian ASI ekslusif di Desa Pucanganom yaitu faktor pemudah, faktor pendukung dan faktor pendorong

2. Faktor pemudah meliputi tingkat pendidikan dengan prosentase terbanyak ibu yang memberikan ASI eksklusif adalah SMA sampai $\mathrm{S} 1(70 \%)$ dan pengetahuan tentang pemberian ASI eksklusif $(93,33 \%)$, serta didukung nilai budaya keluarga dalam pemberian ASI eksklusif (100\%).

3. Faktor pendukung meliputi kesehatan ibu dimana hampir seluruh ibu dalam kondisi sehat $(96,67 \%)$ dan ketersediaan pemberian ASI tepat waktu (80\%).

4. Faktor pendorong meliputi dukungan keluarga dengan prosentase $(80 \%)$ dan dukungan petugas $(93,3 \%)$.

\section{SARAN}

1. Bagi ibu-ibu

Bagi ibu-ibu baik ibu rumah tangga atau ibu yang bekerja sebaiknya terus memberikan ASI Eksklusif selama 6 (enam) bulan untuk bayinya karena ASI merupakan makanan terbaik untuk bayi dan menunjang tumbuh kembang bayi.

2. Bagi institusi kesehatan

Puskesmas dapat melakukan penyuluhan kesehatan melalui kader kesehatan tentang 
pentingnya ASI kepada ibu yang bekerja.

3. Bagi peneliti selanjutnya

Hasil penelitian ini sebagai data awal untuk meneliti tentang ASI Eksklusif dengan tumbuh kembang.

\section{DAFTAR PUSTAKA}

Ariani, Ayu Putri. Aplikasi Metodologi Penelitian Kebidanan dan Kesehatan Reproduksi. Yogyakarta: Nuha Medika, 2014.

Diyono. Buku Ajar Metodologi Penelitian Keperawatan. Surakarta: Akper Panti Kosala, 2014.

Hartono, Rudi dan Sulis Setianingsih. Manfaat ASI Eksklusif untuk Buah Hati Anda. Yogyakarta: Pustaka Baru, 2014.

Hidayat, A. Aziz Alimul. Metode Penelitian Kebidanan dan Tehnik Analisis Data. Jakarta: Salemba Medika, 2009.

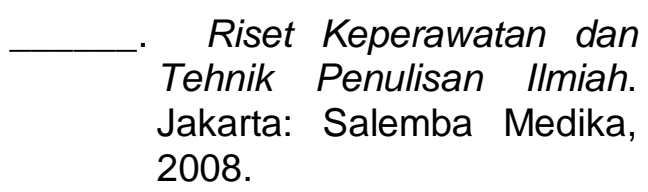

Indiarti, MT. Panduan Lengkap Kehamilan, Persalinan dan Perawatan Bayi Bahagia Menyambut Si Buah Hati. Jakarta: Diglossia Media, 2009.

Maryunani, Anik. Perilaku Hidup Bersih dan Sehat (PHBS). Jakarta: CV. Trans Info Media, 2013.
Mueser, Anne Marie. Panduan Lengkap Perawatan Bayi dan Anak A-Z. Yogyakarta: Diglossia Media, 2009.

Proverawati, Atikah dan Eni Rahmawati. Kapita Selektif ASI dan Menyusui. Yogyakarta: Mulia Medika, 2010.

Rosita, Syariah. ASI Untuk Kecerdasan Bayi. Yogyakarta: Ayyana, 2008.

Saleha, Sitti. Asuhan Kebidanan Pada Masa Nifas. Jakarta: Salemba Medika, 2009.

Simanjuntak, Lamria. Faktor-faktor Dominan yang Mempengaruhi lbu dalam Pemberian ASI Eksklusif Di Wilayah Kerja Puskesmas Belgie. Diunduh 10 Juli 2014.

Rahmawati, Meiyana Dianning. Faktor-faktor yang Mempengaruhi Pemberian ASI Eksklusif Pada ibu Menyusui Di Kelurahan Pedalangan Kecamatan Banyumanik Kota Semarang. Diunduh 10 juli 2014.

\section{Dosen AKPER Panti Kosala Surakarta \\ 2 Mahasiswa AKPER Panti Kosala Surakarta}

